\title{
Good teachers are needed?
}

\author{
LAWRENCE WEINSTEIN \\ Marymount College of Kansas, Salina, Kansas
}

\begin{abstract}
Contemporary academic use of a number of typically seen items on teaching evaluation devices appears to be counterproductive. That is, attempts to identify teachers who have the qualities on the evaluation instruments and those who lack these qualities (with the idea of changing the have-nots to haves) will too often locate well-liked, affable, interesting lecturers who produce students who do not learn very much.
\end{abstract}

Why should university/college teachers alter their way of life? Because what they do can be improved; this is the typical answer in today's institutions of higher learning. Teaching can be made better so that students learn more-so that they come away from a class with the greatest possible increase in their knowledge of the subject. The way to teacher improvement lies, first, in identifying what is wrong with the teachers' performance. Second, the teachers must change the identified weaknesses in the desired direction.

In the main, today's universities and colleges identify bad and good teachers through students' and peers' evaluations of in-class teaching performance. Indeed, it is probably fair to say that in many institutions, initial appointments, promotions, granting of tenure, and merit raises are at least to some extent based upon these methods of measuring teachers' effectiveness.

I have serious questions about the assumption that students' and peers' evaluations are valid tools to use in identifying good and bad teachers. There is evidence that points to two facts: (1) Teachers who score high on both students' and peers' in-class evaluations do not usually produce students who predictably score high on standardized tests of academic achievement, and do not typically produce students who predictably score high on more usual nonstandardized classroom examinations. In other words, studies (e.g., Coker, Medley, \& Soar, 1980) have demonstrated that supposedly good teachers (as indicated by peers' and students' evaluations) do not usually produce particularly knowledgeable students or particularly ignorant students. (2) Perhaps even more distressing is the finding (Coker et al., 1980) that teachers judged outstanding by students and peers quite often produce students who come away from the class knowing less than the students of teachers who were judged as poor teachers. Possibly most unnerving is the converse finding (Coker et al., 1980) that supposedly bad teachers produce students who score higher on standardized and nonstandardized tests of knowledge than students from classes taught by good teachers. In essence, recent data suggest that teachers who are judged as outstanding by students and peers either

Request for reprints should be sent to Lawrence Weinstein, Department of Psychology, Marymount College of Kansas, Box 5050, Salina, KS 67402. produce no predictable degree of learning in students or are doing a bad job of educating people.

Coker et al. (1980) clearly demonstrated that the results from in-class peer evaluations of teachers either bore no relationship to students' scores on standardized academic achievement tests and tests of self-esteem or bore a relationship opposite to what would be expected. Students whose teachers were rated outstanding in several traits typically thought to be good teacher traits showed belowaverage improvement for their grade. Some of the teacher skills that had negative effects on students' academic achievement test scores included keeping students on the assigned task, using a variety of teaching methods, using nonverbal communication, using praise and rewards, eliciting students' queries, responding to students' queries, giving students a voice in making decisions in class, making contact with a student who is off the task, and providing one-to-one counseling with the student. The results are disturbing. It would seem that items frequently seen on students' and peers' teacher evaluation instruments (i.e., allows students to ask questions, the teacher answers questions, lets students participate in decisions regarding the course format, etc.; is well-liked by students) should be there, but should receive an interpretation $o p$ posite to the usual one. Low scores on these items indicate good teachers, teachers who produce students who do well on school tests.

Weinstein (1981b) demonstrated that college teachers who scored high on students' evaluations tended to produce students who scored lower on nonstandardized academic achievement tests than students who were taught by teachers who scored lower on students' evaluations. Furthermore, the same study showed that the lowerachieving students spent less time studying the course material than did the higher-scoring students. Highscoring teachers had students who did not do as well on examinations and did not study the course material as well (or as much) as did the students of lower-scoring teachers.

In a related study, Weinstein (1981a) demonstrated that the more time a teacher was available to his/her students outside the classroom, the less well his/her students did on nonstandardized achievement tests.

Does this mean that $100 \%$ of teachers who score high on evaluations are bad teachers? Probably not. All of these 
data are group data. Quite possibly there are individuals within the group who do not behave like the group as a whole. What the results make evident, though, is that the validity of judging teachers' competence by students' and peers' evaluations is at the very least doubtful. Data are needed to show us, not what makes good teachers (as this may not be significantly related to high levels of student learning), but what curriculum variables produce students who learn much. To be sure, there are differences in the qualities (motivation, intelligence) of students that will affect students' learning.

A possible explanation of the negative correlations found in Coker et al.'s (1980) study and possible variables that would increase students' learning are selfdirected work and students' attention. A teacher who is terribly interesting and likable may be too good: That is, he/she may encourage the student to listen to (because he/she is truly interesting) and idolize the teacher, may engender too much concern with himself/herself (intentionally or unconsciously), and so lead the student away from what should be his/her primary focus-notetaking, the books, and the subject matter. Indeed, some lecturers may be so good that a student would rather passively listen to him/her without taking notes on the talk. Moreover, the preliminary evidence (Weinstein, 1981a, 1981b) cited above indicates that there is a significant negative correlation between how much students like a teacher, or how much time students spend in the teacher's office seeking help, and how much time (in hours) students spend studying for that teacher's course. That is to say, students who like a teacher very much and/or frequently seek his/her help outside class do not tend to study their course material as much as students who do not like the professor very much and/or do not seek his/her help. In other words, the teacher traditionally thought to be excellent (i.e., one who is likable and promotes close student-faculty contact) may be the salient, overriding factor in the course, to the detriment of the course material.

However, it seems a good bet even at this point that Coker et al.'s (1980) and Weinstein's (1981a, 1981b) data make the too-often neglected point that to continue to base important academic (and career) decisions on students' and peers' teaching evaluations, which measure nonacademic traits (e.g., the professor's likability), is questionable; moreover, to attempt to alter a university or college professor's professional (teaching) behavior in the direction of teacher evaluations, as these evaluations exist at present, is, at least in some cases, deleterious to the quality of our educational system if our goal is to have students learn.

These few data are potentially quite valuable. What are needed now are more controlled studies to provide evidence on the possible relationships found thus far.

\section{REFERENCES}

Coker, H., Medley, D. M., \& Soar, R. S. (1980). How valid are expert opinions about effective teaching? Phi Delta Kappan, 62, 131-149.

WEINSTEIN, L. (1981a). Student academic performance as a function of university/college professor office availability time. Unpublished manuscript.

WeINSTEIN, L. (1981b). University college students who like you or who come to see you, do not study. Unpublished manuscript.

(Manuscript received for publication December 1, 1986.) 